\begin{abstract}
Коломісць Тетяна, кандидат психологічних наук, доцент кафедри психології розвитку та консультування

ORCID iD:0000-0002-6883-8796

Тачук Валентина, здобувач вищого освітнього ступеня «Магістр», спеціальності «Психологія» Житомирського державного університету імені Івана Франка DOI https://doi.org/10.35619/prap_rv.vi13.138
\end{abstract}

\title{
ЧИННИКИ ЗАДОВОЛЕНОСТІ ШЛЮБОМ НА РІЗНИХ ЕТАПАХ ДОРОСЛОСТІ
}

\begin{abstract}
Анотація. $\quad$ У статті презентовано результати емпіричного дослідження взаємозв'язку чинників задоволеності илюбом та етапами дорослості. Проаналізовано причини конфліктів у молодих сім'ях, зокрема: порушення рольових очікувань подружжя, розбіжності у питаннях виховання дітей, стосунків з родичами $i$ друзями, а також неузгодженості норм поведінки, обумовлених особистісними особливостями. 3 'ясовано, щяо узгодженість сфер значущиості утворює загальну узгодженість сімейних иінностей подружжя. Виявлено вплив узгодженості сімейних иінностей в сфері соиіальної активності та емочійно-терапевтичною сфері на задоволеність шлюбом трьох груп. Присутній взаємозв'язок між показниками узгодженості сімейних иінностей і рольовою адекватністю подружжя в різних сферах сімейних иінностей, щуо характеризує узгодженість иіннісної сфери подружжя передбачає не тільки досягнення когнітивної згоди, але й узгодженість рольової поведінки шлюбних партнерів. Констатовано вплив батьківсько-виховної сфери на задоволеність илюбом для груп на третьому етапі дорослості. Пари другої групи стосовно установки на особистісну ідентифікацію зі илюбним партнером більше начілені на установку щуодо особистої автономії.
\end{abstract}

Ключові слова: етапи дорослості, подружжя, сімейні цінності, задоволеність илюбом, рольові очікування, конфліктні ситуації.

Постановка проблеми. Трансформаційні поцеси, які відбуваються у сучасному суспільстві впродовж останніх десятиліть, призводять до суттєвих змін у функціонуванні сім'ї. Відмова від офіційного укладання шлюбу, висока частота розлучень, зростання кількості дистантних сімей тощо призводять до побутування уявлень про знецінення сім’ї як соціального інституту. Відтак існує реальна загроза формування деформованої моделі сім'ї у свідомості сучасної дитини, що може призвести до вкрай негативних наслідків у мабутньому. Саме тому, одним із надважливих завдань сучасної психологічної науки $\epsilon$ пошук шляхів зміцнення сімених цінностей та збереження сім’ї. Дослідження ж та аналіз психологічних чинників задоволеності шлюбом на різних етапах дорослості може стати важливим кроком у цьому напрямі.

Аналіз останніх досліджень і публікацій. Дослідженням задоволеності подружнього життя вивчається багатьма, як закордонними, так і вітчизняними авторами. Так важливі для концептуалізації феномену засади знаходимо в працях Альошиної, Голод, Гурко, Ейдеміллера, Навайтіса, Сисенко, Фелдмана, Шавлова, Юстицкиса, Юркевича та інших. У численних роботах вітчизняних дослідників (Альошина, Андрєєвої, Голод, Сгорової, Керіг, Сисенко, Шнейдер, Юркевич.) розглядаються різні аспекти проблеми задоволеності подружжя шлюбом. Однак результати досліджень психологічних чинників задоволеності шлюбними стосунками на різних стадіях дорослості є або вже застарілими, або потребують 
уточнення відповідно до сучасних культурно-історичних умов.

Враховуючи труднощі, які переживає сучасна сім'я з одного боку, і недостатність наукового знання про чинники задоволеності шлюбом, як орієнтирів для визначення напрямків надання психологічної допомоги сім'ї - 3 іншого, зумовили вибір теми дослідження.

Метою статті $є$ проведення емпіричного дослідження взаємозв'язку чинників задоволеності шлюбом на різних етапах дорослості.

Виклад основного матеріалу дослідження. Аналіз теоретичних досліджень дозволив встановити, що для гармонійного функціонування сім'ї недостатньо матеріального благополуччя i відповідного рівня освіти. В якості одного 3 найважливіших чинників стійкості подружніх відносин виступає взаєморозуміння між подружжям, що є наслідком безлічі різних впливів (Маринкевич, 2013). Тому психологу важливо знати і вміти діагностувати спільність уявлень подружжя про їхні стосунки i, як наслідок, міру узгодженості їх поведінки.

У якості чинників задоволеності шлюбом називають успішну адаптацію подружжя в суб'єкт-суб'єктних стосунках (Клапішевська, 2012), здатність членів подружжя до саморозкриття, глибокого взаєморозуміння, прийняття поглядів і поведінки партнера (Левкович, 2009), наявність спільного смислового поля процесі спілкування (Rawicka, 2017). Ефективність міжособистісної взаємодії подружжя багато в чому залежить від особливостей ïx емпатійного ставлення один до одного: без співпереживання, співчуття, співучасті неможливо побудувати щирі, довірливі, підтримуючі стосунки. В той же час емпатійне проникнення є механізмом забезпечення точності в комунікації, єдиного смислового поля, адекватного реагування між подружжям (Журавльова, 2007). Відтак, на підставі проведеного теоретичного аналізу з проблеми вивчення психологічних аспектів подружніх відносин на етапі становлення молодої сім'ї було спроектовано психологічне дослідження, метою якого було дослідження зв'язку задоволеності шлюбом на різних етапах дорослості. Об'єкт дослідження: чинники задоволеності шлюбом.

У дослідженні взяли участь 60 подружніх пар. Досліджувані були поділені на три групи: I група - молоді сім'ї (зі стажем подружнього життя до 5 років) віком від 18 до 30 років; II група - подружні пари середньої тривалості шлюбу (стажем подружнього життя від 5 до 10 років) віком від 31 до 50 років; III група - подружні пари, які перебувають у шлюбі більше 10 років (віком від 51 року). Для емпіричного дослідження рівня задоволеності шлюбом використовувалася методика тест Лаки «Вимірювання рівня задоволеності подружжя шлюбом» (Алешина, 1987). Результати діагностики показали (див. табл.1), що в переважній більшості (від 65\% до 75\% - у пар, які перебувають у шлюбі понад 10 років та до 10 років відповідно) досліджувані пари демонструють середній рівень задоволеності шлюбом. Разом 3 тим простежується чітка тенденція до зростання показників діагностованого критерію зі зростанням тривалості перебування в шлюбі. Так, високий рівень задоволеності шлюбом виявлено у 10\% представників молодих сімей, $15 \%$ досліджуваних із середньою тривалістю перебування у шлюбі та 35 \% осіб, шлюб яких триває понад 10 років. Відповідним чином спостерігаємо таке ж рівномірне зниження показників низького рівня задоволеності зі зростанням тривалості подружнього життя.

Показники рівня задоволеності шлюбом залежно від його тривалості

Таблиия 1

\begin{tabular}{|c|c|c|c|}
\hline \multirow{2}{*}{ Рівень задоволеності шлюбом } & \multicolumn{3}{|c|}{ Кількісні показники різних рівнів задоволеності (у \%) } \\
\cline { 2 - 4 } & $\begin{array}{c}\text { до 5 років } \\
\text { (І група) }\end{array}$ & $\begin{array}{c}5-10 \text { років } \\
\text { (ІІ група) }\end{array}$ & $\begin{array}{c}\text { більше 10 років } \\
\text { (ІІІ група) }\end{array}$ \\
\hline високий & 10,0 & 15,0 & 35,0 \\
\hline середній & 75,0 & 75,0 & 65,0 \\
\hline низький & 15,0 & 10,0 & 0,0 \\
\hline
\end{tabular}

Отримані нами результати суттєвим чином відрізняються від тих, які описані у цілій 
низці аналогічних зарубіжних досліджень (Левченко, 2017; Маринкевич, 2013 та ін.). В багатьох опрацьованих публікаціях описується V-подібний характер залежності задоволеності шлюбом від його тривалості: спочатку, впродовж перших п'яти років існування сім'ї, задоволеність шлюбом поступово знижується, досягаючи свого мінімального рівня в парах зі стажем від 5 років спільного життя, а потім різко зростає. Відмінність в результатах пов'язуємо 3 різними культурно-історичними умовами досліджень та поширеною нині тенденцією до розірвання шлюбів на ранніх етапах його існування та в період кризи. Відповідно пари, які мають високий рівень незадоволеності шлюбом просто могли не увійти в нашу вибірку, оскільки вони або вже розпалися, або знаходилися на етапі розлучення, або у них спрацьовували захисні механізми і люди відмовлялися брати участь у дослідженні.

На другому етапі нашого дослідження проводилася діагностика поведінки пар у подружніх конфліктах. За допомогою методики «Взаємодія подружжя в конфліктних ситуаціях» Альошиною і. Гофмана (Алешина, 1987) визначалися найбільш конфліктні сфери подружніх взаємин, рівень конфліктності в сім'ї, міра розбіжностей в конфліктних ситуаціях, активність і модальність емоційних реакцій. У результаті дослідження з'ясовано (рис.1), що в молодих сім'ях, на відміну від зрілих, більш поширеними причинами конфліктів $\epsilon$ розбіжності у поглядах щодо виховання дітей і конфлікти та стосунки з родичами і друзями. Конфлікти, що пов'язані з порушенням рольових очікувань частіше виникають у представників третьої групи ніж першої та другої. Водночас найвищий рівень конфліктності виявлено у представників першої групи, що пов'язуємо з періодом адаптації до шлюбу, шлюбного партнера, спільного побуту тощо.

Табличя 2

Результати методики «Взаємодія подружжя у конфліктних ситуаціях» за критерієм «конфліктність»

\begin{tabular}{|l|c|c|c|}
\hline \multirow{2}{*}{ Типи взаємодії } & \multicolumn{3}{|c|}{$\begin{array}{c}\text { Показники наявості різних типів конфліктності у } \\
\text { сімейних парах }\end{array}$} \\
\cline { 2 - 4 } & до 5 років & $\mathbf{5 - 1 0}$ років & більше 10 років \\
\hline активна не конфліктна & 5,0 & 10,0 & 0,0 \\
\hline пасивна не конфліктнаий & 5,0 & 20,0 & 20,0 \\
\hline пасивна конфліктна & 70,0 & 70,0 & 75,0 \\
\hline активна конфліктна & 20,0 & 0,0 & 5,0 \\
\hline
\end{tabular}

Водночас було з'ясовано (табл.2), що в I групі при взаємодії подружжя в конфліктах ситуаціях виявляють негативні реакції у всіх перерахованих ситуаціях. Молоді пари, порівняно зі зрілими, є значно активнішими в своїх реакціях (за винятком розбіжностей щодо грошей і при порушені рольових очікувань). Рівень конфліктності в I групі вище, ніж в III групі. I група в своїх реакціях активніша, ніж II і III групи (за винятком розбіжностей щодо грошей і при порушені рольових очікувань). У І групі при взаємодії подружжя в конфліктах виявляють негативні реакції у всіх сферах подружніх відносин. Значні розбіжності між подружжям виявляється в ситуаціях, пов'язаних з родичами і друзями, 3 питань виховання дітей, прояви автономії, неузгодженості норм поведінки, ревнощів і ставлення до грошей.

Діагностика подружніх пар за методикою «Визначення узгодженості сімейних цінностей і рольових установок в подружній парі (РОП)» ( Волков) дозволила констатувати (рис.1). В подружніх стосунках існує взаємозв'язок ступеня значущості для шлюбних партнерів за утворення різних сфер сімейно-рольової взаємодії й сімейних цінностей. Відповідно існує загальна тенденція із узгодженості сфер ціннісної та сімейно-рольової взаємодії. Насамперед ціннісна узгодженість визначена між соціальною активністю та емоційно-терапевтичною. 


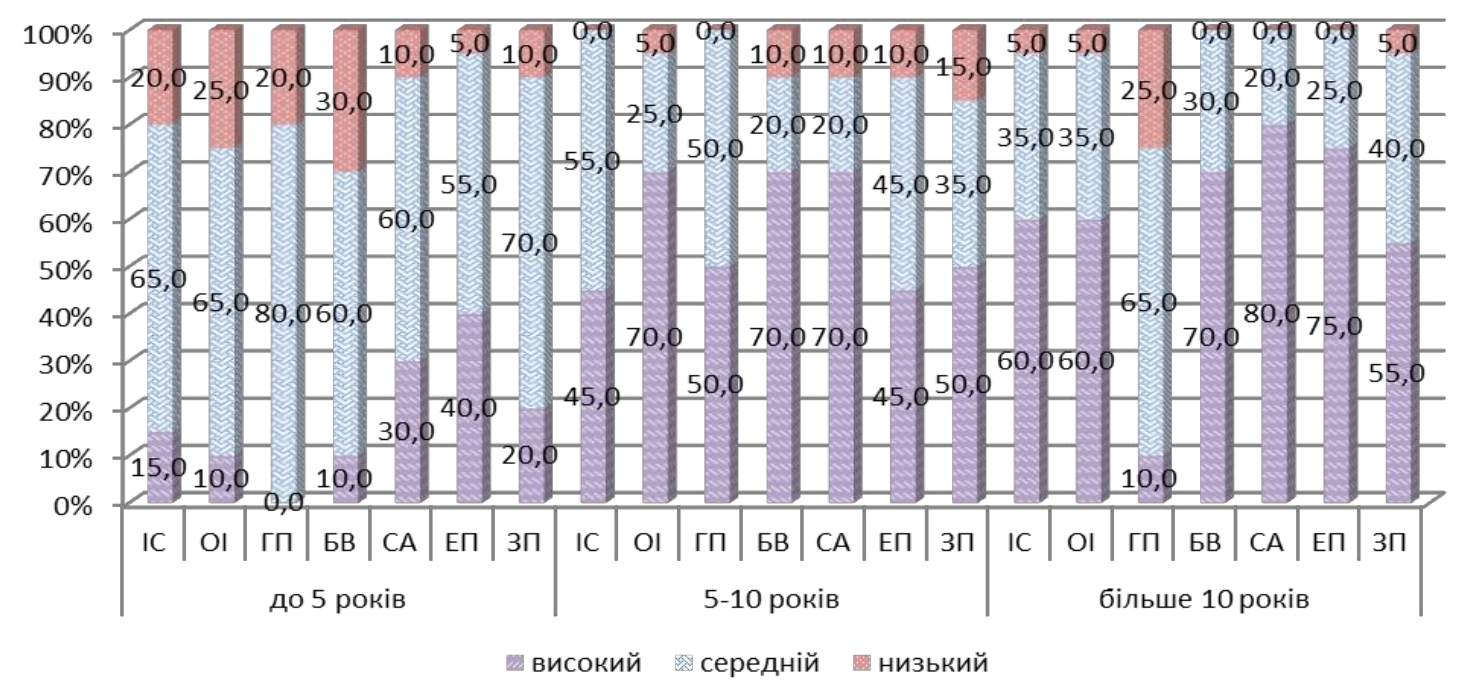

\section{Рис. 1. Результати методики «Визначення узгодженості сімейних цінностей i рольових установок в подружній парі (РОП)», \%}

У I та III групі виражено зв'язок між емоційно-терапевтичною сферою та сферою соціальної активності, шкала соціальної активності віддзеркалює пристосування на суть зовнішньої соціальної активності (суспільної, професійної) для покращення сімейних відносин. Спільна оцінка шкали формулює сутність позашлюбних зацікавлень для подружніх пар, які є головними цінностями в ході міжособистісної взаємодіянні пари.

Результати вказують, що емоційно-психотерапевтична шкала виражає установку на сутність емоційно-психотерапевтичної діяльності подружжя, на те, що глава сім'ї буде відображати функцію емоціонального лідера в сім'ї у запитаннях: коректування психологічного клімату в сім'ї, надання морального та емоційного сприяння. Спільна оцінка шкали аналізується як ознака цінності для подружніх пар обопільної внутрішньої та чуттєвої допомоги членів сім'ї, орієнтації на подружжя як сферу, яка сприятиме психологічної розрядки і стабілізації.

У групі II досліджуваних виражено зв'язки між згодою сімейних цінностей в сфері соціальної активності, у сфері особистісної ідентифікації, батьківсько-виховної сфери, що свідчить на більш злагоджені відношення та урівноважені. Таким чином, шкала особистісної ідентифікації показує пристосування сімейної пари на особисту ідентифікацію з подружнім партнером: очікування єдності зацікавлень, ціннісних орієнтацій, потреб, прийомів загальнопроведення часу разом. Невисокі оцінки за шкалою допускають пристосування на індивідуальну автономію. Школа батьківського виховання допускає визначати про ставлення подружжя до своїх батьківських обов'язків, вираженість установки пари на життєдіяльну батьківську поведінку шлюбного партнера, зображає орієнтації подружньої пар на особисті обов'язки у вихованні дітей. Спільна оцінка шкали аналізується як дані значущості для пари батьківських ролей. Високе поняття шкали, тим найбільшої важливості надає пара ролі матері (батька), тим більше вона (він) допускає батьківствою центральною вартістю, зосереджує довкола себе на житті сім'ї.

Шкала соціальної активності показує установку на сутність зовнішньої соціальної активності (суспільної, професійної) для стабільності шлюбно-сімейних стосунків, що формулює сутність позасімейних зацікавлень для подружніх пар, які $є$ головними цінностями в ході особистісної взаємодії пари. Виражено зв'язки між даними рольовою узгодженості сімейних цінностей в різноманітних сферах сімейних цінностей і адекватністю подружжя (за шкалами методики “Рольові очікування та домагання у шлюбі”). Отже, узгодженість рольової поведінки шлюбних партнерів, але й узгодженість ціннісної сфери подружжя призначає не тільки успіхи когнітивної згоди. Результати дослідження виразили вплив соціально активної та згоди сімейних цінностей в сферах емоційно-терапевтичної на задоволеність шлюбом I, II, III груп. Також, виражено вплив вартості для III групи 
батьківсько-виховної сфери на задоволеність шлюбом. Можемо відзначати, що шлюбні пари II групи сильніше націлені на пристосування щодо власної автономії. Отож, в процесі психодіагностичного дослідження можливо відзначати, що сумісність подружжя виділяється взаємодоповнюючими розуміннями партнерів на рольові очікування, сімейні цінності та побажання, і так само рівнем задоволеності у шлюбі. Проведений кореляційний аналіз підтвердив висунуту гіпотезу, що складається з припущення, що між рівнем і чинниками задоволеності шлюбом та етапами дорослості існує взаємозв'язок.

Висновки і перспективи подальших розвідок. Причиною конфліктів в молодих сім'ях $є$ порушення рольових очікувань подружжя, розбіжності з питань виховання дітей, стосунків з родичами і друзями, а також неузгодженості норм поведінки, обумовлених особистими особливостями. Рівень конфліктності в I групі вище, ніж в III групі. I група в своїх реакціях активніша, ніж II і III групи (за винятком розбіжностей щодо грошей і при порушені рольових очікувань). У І групі при взаємодії подружжя в конфліктах виявляють негативні реакції у всіх сферах подружніх відносин. Значні розбіжності між подружжям виявляється в ситуаціях, пов'язаних з родичами і друзями, з питань виховання дітей, прояви автономії, неузгодженості норм поведінки, ревнощів і ставлення до грошей.

На основі взаємозв'язку між даними цінності сфер сімейних цінностей, узгодженості сімейних цінностей, рольової адекватності та показниками сімейного благополуччя подружжя можливо вказувати, що узгодженість цих складових сімейно-рольової взаємодії $\epsilon$ ознакою загальної узгодженості функціонально-рольової структури сім’ї. За результатами аналізу розкрито існуючий вплив взаємоузгодженості сімейних цінностей за сферами соціальної активності й емоційно-терапевтичної на задоволеність шлюбом на різних етапах дорослості. Окрім того, присутній значний вплив для третьої групи саме батьківськовиховної сфери на задоволеність шлюбом.

\section{СПИСОК ПОСИЛАНЬ}

Алешина, Ю. (1987). Характер взаимодействия супругов в конфликтной ситуаџии. Методы исследования межличностного восприятия. Спецпрактикум по социальной психологии. Москва.

Журавльова, Л. П. (2007). Психологія емпатї. Житомир: Житомирський державний університет ім. Івана Франка.

Клапішевська, С. А. (2012). Теоретико-методологічні засади дослідження проблеми задоволеності шлюбом. Актуальні проблеми соціологї, психологї, педагогіки, 17, 114120.

Левкович, В. П. (2009). Особенности добрачных отношений супругов как фактор стабилизации семьи. Психологический журнал, 2, 88-89.

Левченко, М. А. (2017). Факторы удовлетворенности браком супругов на стадии диады. Научные еисследования: теория, методика и практика. (с. 144-146). Чебоксары: ЦНС "Интерактив плюс".

Маринкевич, С. М. (2013). До питання про задоволеність шлюбом як індикатор функціонування сімейної системи. Філософія. Культура. Життя, 39, 252-262.

Rawicka, I. (2017). Cechy temperamentalne a satysfakcja ze związku. Polskie Forum Psychologiczne, 22, 4, 623-635.

\section{REFERENCES}

Aleshyna, Y. U. (1987). Kharakter vzaymodeystvyya supruhov v konflyktnoy sytuatsiy [The nature of the interaction of spouses in a conflict situation]. Research methods of interpersonal perception. Special workshop on social psychology. Moskva. [in Russian].

Zhuravlova, L. P. (2007). Psykholohiya empatiyi [Psychology of empathy]. Zhytomyr: Zhytomyr Ivan Franko State University. [in Ukrainian].

Klapishevska, S. A. (2012). Teoretyko-metodolohichni zasady doslidzhennya problemy zadovolenosti shlyubom [Theoretical and methodological principles of the study of the 
problem of marriage satisfaction]. Current issues in sociology, psychology, pedagogy, 17, 114-120. [in Ukrainian].

Levkovych, V. P. (2009). Osobennosty dobrachnykh otnoshenyy supruhov kak faktor stabylyzatsyy sem y [Features of virtuous relations of spouses as a factor of family stabilization]. Psychological journal, 2, 88-89. [in Russian].

Levchenko, M. A. (2017). Faktory udovletvorennosty brakom supruhov na stadyy dyady [Factors of satisfaction with lack of spouses at the stage of dyads]. Scientific Research: theory, methods and practic. (s. 144-146). Cheboksary: CNS "Interactive Plus". [in Russian].

Marynkevych, S. M. (2013). Do pytannya pro zadovolenist shlyubom yak indykator funktsionuvannya simeynoyi systemy [To the question of marriage satisfaction as an indicator of the functioning of the family system]. Philosophy. Culture. Life, 39, 252-262. [in Ukrainian].

Rawicka, I. (2017). Sechy temperamentalne a satysfakcja ze związku. Polskie Forum Psychologiczne, 22, 4, 623-635.[in Polish].

\title{
THE EXPERIMENTAL STUDY OF THE RELATIONSHIP FACTORS OF MARRIAGE SATISFACTION DATA AND ADULTS
}

Tetiana Kolomiiets,

Candidate of psychological sciences, Associate professor, Department of psychology of development and concealing ORCID iD: 0000-0002-6883-8796

Valentyna Tkachuk, graduate student, specialty "Psychology" Zhytomyr Ivan Franko State University DOI https://doi.org/10.35619/prap_rv.vi13.138

\begin{abstract}
The article is devoted to the peculiarities of the relationship between factors of marriage satisfaction and stages of adulthood. The author draws attention to the causes of conflicts in young families in the direction of violation of the role expectations of spouses, disagreements on child-rearing, relations with relatives and friends, as well as inconsistencies of behaviors due to personal characteristics. The results of the analysis revealed the influence of coherence of family values in the sphere of social activity and emotional-therapeutic sphere on the satisfaction of the marriage of the three groups. In addition, the influence of significance for group III of the parenteducational sphere on the satisfaction with marriage was revealed. Indicators of the components of communicative tolerance show significantly the influence of the age factor of the experience of married couples studied on the results of the study: indicators of the first group of subjects (up to 5 years) are significantly more tolerant than those of the second and third groups (5-10 years and 10 years) on the following scales: forgive others the mistakes, inconveniences, unintentionally caused you troubles "," Intolerance to physical and mental discomfort created by other people "," The inability to forgive others mistakes, inconveniences, unintentionally cause no trouble for you "," Intolerance to physical and mental discomfort created by other people "; studied II and III groups in comparison with the indicators of the first group studied more tolerant on the scales: "Using yourself as a standard in assessing the behavior and way of thinking of other people", and "Inability to adapt to the character, habits and desires of others."

The above features of the general communicative tolerance (intolerance) of the studied couples and features of different age groups of the studied will be taken into account when conducting the corresponding psycho-corrective program. Our correlation analysis confirmed our hypothesis, which consists of the assumption that there is a relationship between the level and factors of satisfaction with marriage and stages of adulthood.
\end{abstract}

Keywords: stages of adulthood, satisfaction with marriage, role expectations, conflict situations.

Стаття надійшла до редакиії 21.09.2019 p. 